\title{
Az Állattani Szakosztály ülései (2017. december 6. - 2018. november 7.)
}

\author{
TÓTH BALÁZs* \\ Magyar Természettudományi Múzeum Állattára, 1088 Budapest, Baross u. 13. \\ E-mail: toth.balazs@nhmus.hu
}

Fontos újdonságként megemlítendő, hogy az előadásokról videófelvételek készülnek, amelyek szerkesztés után felkerülnek a Szakosztály nyilvános YouTube-csatornájára. Ennek megfelelően a levezető elnök minden előadóülés elején bejelenti, hogy az előadások a továbbiakban videokamerával rögzítésre kerülnek, és a felvételeken történő megjelenést a hallgatóság tagjai az ülésen történő további részvétellel vállalják. A felvételek rögzítését, szerkesztését és feltöltését SULYÁN PÉTER végzi, akinek ezúton is köszönetemet fejezem ki, mert munkájával nagymértékben megkönnyítette jelen összefoglaló elkészítését.

\section{2. előadóülés, 2017. december 6-án}

Az ülést KITAIBEL PÁL emlékének szenteltük, halálának 200. évfordulója alkalmából. NAGY PÉTER, az Állattani Szakosztály elnöke vezette le.

1. Ifj. PAPP LÁSZLÓ: KITAIBEL PÁL életútja.

Előadó az előadás bevezetőjében hangsúlyozta KITAIBEL PÁL polihisztor voltát, ezután ismertette életútját. Sokáig maga KITAIBEL sem tudta, hogy mikor született, levéltári anyagból derült ki számára, hogy 1757. február 3-án látta meg a napvilágot Nagymartonban (ma Ausztria). A nemrég Nagyszombatból Budára költözött Királyi Magyar Tudományegyetemre iratkozott be orvostanhallgatónak, ugyanis akkor még csak ezen a szakon volt lehetőség botanikával foglalkozni. Tanulmányi eredményeiért és emberi értékeiért Genselösztöndíjat nyert el, majd WINTERL JAKABhoz, a kémiai és botanikai tanszék, majd a Füvészkert megalapítójához került. Eleinte elkísérte felfedezőútjaira, majd WINTERLtől átvette gyógyvízkutatásait. Tudományos eredményeinek köszönhetően negyedévesen már adjunktusnak nevezték ki. A botanikus kert időközben Pestre (a mai Ferenciek terére) költözött. KITAIBEL nagy segítséget nyújtott WINTERLnek a költözésben, maga szolgálati lakást kapott itt, így sok időt tölthetett a kert gondozásával. WINTERL JAKAB elkészítette a botanikus kert első magcserekatalógusát, amely más füvészkertek számára cserére szánt magvak faját és darabszámát tartalmazta. Mind a mai napig szokás ilyen katalógusok készítése, és ezek alapján magvak cseréje a botanikus kertek között. A Helytartótanácstól utasítást kapott a Kárpát-medence élővilágának kutatására, feldolgozására. Hamarosan egyetemi tanárrá nevezték ki, ám órákat nem tartott, viszont korrepetált. Tizenhat gyüjtőúton vett részt szerte a

*Az Állattani Szakosztály jegyzője 
Kárpát-medencében, ahol nemcsak botanikai, hanem állattani, néprajzi és geológiai adatokat is gyüjtött. A hozott növényeket a Füvészkertbe telepítette, ezzel megháromszorozta a kert fajszámát. Újabb költözésnek nézett elébe a kert, KITAIBEL ebben - megromlott egészségi állapota ellenére is - nagy segítséget nyújtott. Először kémiai munkássága virágzott fel. MÜLLER FERENC után néhány évvel fedezi fel a tellúrt, melynek leírását egy német vegyész jelentette meg, aki MüLLERt nevezte meg az elem felfedezőjének. Nagyjából 150 forrás vizének vegyelemzését végezte el. Botanikai kutatásait a Budai-hegységben kezdte. Sok új növényfajt fedezett fel, de ezeket csak később, nagy összefoglaló művekben publikálta. A herbáriumi lapokat gyakran nem a begyüjtött példányokból, hanem azoknak a Füvészkertben nevelt utódaiból készítette. A móri földrengésröl jelentést készített. Nevét a Kitaibelia folyóirat is őrzi. Életében nem készült róla portré. NAGY PÉTER az előadás végén megemlítette, hogy az Előadó első előadását tartotta az Állattani Szakosztályban. MERKL OTTÓ érdeklődött afelől, hogy a Füvészkertben látható szobor készítője, KUBOVICS IMRE, azonos-e azzal, aki dékán is volt; a válaszból megtudtuk, hogy igen, ugyanarról a személyről van szó.

\section{SZÖVÉNYI GERGELY: KITAIBEL, a zoológus.}

Bár KITAIBEL nevét általában a botanikával összefüggésben említik, állattani munkássága is jelentős, említésre méltó. Útinaplóiban rögzítette zoológiai megfigyeléseit, melyeket összegezve szándékozott közölni, ám odáig már nem jutott. Külföldre rendszeresen küldött állattani anyagokat, a szerzőség átengedésével. Sokféle ízeltlábúról, puhatestűekről, de még a májmételyről is leírta megfigyeléseit. A gerincesekre jóval nagyobb figyelmet fordított. Részletesen leírja a később Petényi-márna néven ismertté vált halfajt; több évtizeddel korábban, mint ahogy eddig tudni véltük - ám nem nevezte el, és nem publikálta. A többi osztály mellett az emlősökkel is sokat foglalkozott; felismerte a güzüegér faji önállóságát, és értékes megfigyeléseket közölt a földikutyáról is. Kérdések hiányában hamar továbbléptünk a következő előadásra.

3. KorSÓs ZoltÁn: KitAiBEL PÁL (1757-1817) herpetológiai felfedezései.

A herpetológusok között az a szóbeszéd járja, hogy e tudományterület alapmüvének számító müvet nem a szerzőként feltüntetett bécsi LAURENTI, hanem WINTERL JAKAB, KITAIBEL mentora írta. A pannon gyíkot elsőként említette, egyoldalas leírást adott róla, példányaiból Bécsbe is küldött. Bonyolult taxonómiai szituációk kibogozása után csak az 1850-es években született meg érvényes leírása és KITAIBELt megörökítő latin neve. Ö fedezte fel az akkori Magyarország területén a barlangi vakgőtét, a Budai-hegységből is említette a keresztes viperát - nem tudjuk, mit láthatott. „Coluber obscurus” néven FelsőMagyarország fenyveseiből írt le egy kígyófajt, és azt is feljegyezte, hogy a Harsány melletti hegyen élő, nagytermetü, szürkés hátú és viaszsárga hasú kígyót a helybeliek „zumak” néven ismerik - azaz a haragos siklóról is készített feljegyzéseket. Előadó végül felhívta a figyelmet HORVÁTH GÉZA, akkori múzeumi főigazgató, KITAIBELről készített könyvére. Nem hangzott el kérdés az előadás után.

4. CSORBA GÁBOR, FARKAS JÁNOS és NÉMETH ATTILA: Három a magyar igazság - avagy mit sikerült megtudnunk a hazai földikutyákról KITAIBEL PÁL óta?

KITAIBEL PÁL még nem tudott sokat a földikutyákról. Jelenlegi ismereteink szerint az egyetlen, Nyugat-Palearktiszra endemikus emlőscsoport a földikutyáké. MÉHELY LAJOS nagy részletességgel írt a földikutyák alak- és rendszertanáról; e müvet mind a mai napig 
idézik. VÁSÁRHELYI ISTVÁN az életmódját tanulmányozta fogságban tartott egyedek alapján. A Magyar Természettudományi Múzeumban van a világ leginformatívabb földikutyagyüjteménye (genetikai anyagot tekintve is). MÉHELY vett észre összefüggéseket a csontmorfológiai és életmódbéli sajátosságok között, és ebből következtetett a fajok számára. A csoport evolúcióját vizsgálva minden, a törzsfán bekövetkezett szétváláshoz sikerült egyegy, nagy jelentőségü földtörténeti eseményt rendelni (pl. füves puszták kialakulása, szárazföldi kapcsolat átmeneti megszünése a Balkán és Kis-Ázsia között). Az Erdélyi-Mezöség „nagy” földikutyáit a Kárpátok kiemelkedése szigetelte el a moldvai és havasalföldi állományoktól, speciációt keltve. A „kis” földikutyák feltételezett jégkorszaki refúgium területei a nyugat-balkáni magashegységek voltak. A Kárpát-medencében sajnos jelentösen lecsökkent a földikutya fajok állományainak száma, és a megmaradt populációk nagy része nagyon kevés példányból áll. Kiderült ugyanis, hogy hazánkban nem egy, hanem három fajuk él (egy további kipusztult), valamint az Erdélyi-Mezőségben még egy. Ezek klímaigényükben elkülönülnek. Próbálkoztak a földikutyák áttelepítésével, szerencsére sikeresen. Ez a helyzet különlegesen részletes monitorozásra, életmód-kutatásokra is alkalmas. Nagy hangsúlyt fektetnek a földikutyákkal kapcsolatos ismeretterjesztésre, szemléletformálásra is. Az előadás végén NAGY PÉTER afelől érdeklődött, hogy miért nevezték el ezt az állatcsoportot „kutyának”. Előadónak nincsen biztos magyarázata, elképzelhető, hogy alakjuk kutyakölyökre emlékeztette a névadót, ill. a hangjukat is hasonlónak vélhette.

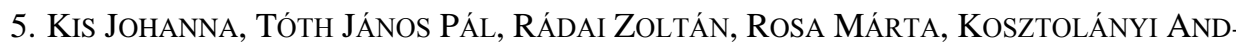
RÁS és BARTA ZOLTÁN: Dimorfizmus a nagyfejü csajkó (Lethrus apterus) bogárfajnál.

KITAIBEL a naszályi útján említi e bogárfajt. Ivari dimorfizmust mutat a bogár rágójának alakja. A szaporodásbiológiájukról szóló közlemények nagy része 100-150 éves. Ezek alapján a bogár március végén jön elö, párkeresés után a két ivar közösen ássa a lárvák keltetésére való járatot. A hím ezután őrzi a fészket, gyüjti a növényeket, míg a nőstény készíti e növényekből a lárvák táplálékául szolgáló labdacsokat. Egy újabb közlemény szerint a nöstények jóval több növényi részt gyüjtöttek, mint a hímek. E megfigyelés alapján Szerzők újra kívánták vizsgálni az ivarok szerepét a fészekkészités különböző mozzanataiban. Kutatásuk egyik kérdése az volt, hogy a nagyobb tömegủ talajt megmozgató (többet ásó) ivar lábszára máshogy néz-e ki, mint a kevesebbet ásó nemé, ill. van-e eltérés az egyes populációk lábszárainak alakjában. Nyolc populációból vettek mintát, mikroszkóp segítségével digitalizálták a lábszárakat. A nőstényeknek egyértelműen görbültebb és szélesebb lábszáruk van, mint a hímeknek. A populációk között nem látszott különbség. Valószínüleg a szélesebb láb alkalmasabb az ásásra, ezért feltehetőleg a nőstények ásnak többet. A fészkeket nehéz kiásni, ugyanis gyakran agyagos talajba készítik, melybe akár $90 \mathrm{~cm}$ mélyre is lehatolnak. A kutatás másik kérdése arra vonatkozott, hogy az ivarok immunitására hogyan hat a szaporodási időszak. Külön-külön vizsgálták az ivarokat, ill. fiatalabb és idősebb egyedeket; a példányok korát a kültakaró simaságából és a lábszárak kopottságából állapították meg. Az immunválasz erősségét egyrészt damildarab bogártestbe ültetésével tanulmányozták (az idegen test körül kialakuló tok elsötétedésének mértéke egyenes arányban áll az egyed immunitásával), másrészt a vérnyirok baktériumölő képességének mértékét vizsgálták. Ezeken kívül megszámolták a példányokon tartózkodó parazita atkákat is. Debrecenben gyüjtöttek közel 80 egyedet, két időszakban. A szezon végén az egyedek erősebb immunválaszt mutattak, mint az elején; ez az eredmény várakozásaikkal ellentétes volt (alaphipotézisük szerint az egyedek kimerülnek a szaporodási időszak végére), továbbá az 
erősebb immunválaszú egyedeken kevesebb atkát találtak, mint a gyengébb immunitásúakon. Az idősebb példányok immunválasza gyengébb volt, mint a fiatalabbaké, és a kisebb példányok is gyengébb immunválaszt mutattak, mint a nagyobbak. Összegzésként Előadó kiemelte, hogy a nőstényeknek nagyobb szerepe van az utódgondozásban, mint a hímeknek, az immunválasz erőssége függ a példányok korától, a szezonalitástól és az egyedek méretétől is.

6. Fehér Zoltán, Majoros GÁbor, Ötvös SÁNDOR, BAJomi BÁlint és Sólymos PÉTER: A fekete bödöncsiga (Theodoxus prevostianus) jövöje a Kárpát-medencében: egy viszszatelepitési program tanulságai.

A fekete bödöncsiga olyan genuszba tartozik, amely családjából egyedüliként él édesvízben. A faj a pleisztocénben jóval elterjedtebb volt, mint ma, amikor általában langyos vizü forrásokban található meg. Élőhelyén igen nagy egyedszámban lehet jelen. Recens populációi általában egyszínủ feketék, ám szubfosszilis egyedei cikkcakk-mintásak is lehetnek. KITAIBEL fedezte fel első, diósgyőri populációját; itt az 1940-es évekig élt a várárokban. Tatai populációi (Fényes-forrás, Angolkert) a szénbányászat karsztvíz-kiemelése miatt bekövetkezett vízszintcsökkenésnek estek áldozatul. Sályon a vízmü foglalta el az élőhelyét jelentő forrást, néha klórral szennyezték. Magyarországon ma már csak Kácson tenyészik. Rendszertani helyzete kérdéses, újabb genetikai eredmények alapján egyes kutatók összevonják a rajzos bödöncsigával (Th. danubialis). Természetvédelmi jelentősége igen nagy (pannon endemizmus), EU Élőhely Irányelv mellékleteiben is szerepel. Mivel hazánkban csak egyetlen populációja maradt, Szerzők felvetették visszatelepítését régi élőhelyeire. Négy helyszín jöhetett szóba, ezek 2009-es felmérése után Sály bizonyult a legígéretesebbnek. Összesen 600 példány áttelepítésére kaptak engedélyt, ez Szerzök szerint nem biztos, hogy elegendő, mert külsőleg látható ivari jellegeket a faj nem hordoz, így előfordulhat, hogy a találomra kiemelt mintában el lesz tolódva az ivararány. Az egyedek szeretnek fajtársaik házára petézni, ezért petéket hordozó példányokat igyekeztek válogatni. Virágcserepekben helyezték őket a patakba, hogy a víz áramlása ne vigye el őket (iszapon nem tudnak megtelepedni); a cserepeket hamar kilopták a helyiek. Az 1. telepítés után néhányszor monitorozták, de az egyedszám az észlelési küszöb alatt maradt. A következö telepítés két év múlva történt, a rá következő három évben továbbra sem találták. Ám ezt követően 5000-20000 közötti egyedszámot tapasztaltak. Az eset tanulsága, hogy folyamatosan kellett volna monitorozni az állományt a kezdetektől. Szerzők feltételezése szerint az átvitt petékből kikelő utódoknak köszönhető a nagy egyedszám és a telepítés sikere. A továbbiakban a sályi állomány megerősítését szeretnék elérni azáltal, hogy növelik a szilárd aljzatú patakszakasz hosszát. Gondolkoznak egyéb helyszínekre történő telepítésben; a tatai Fényes-forrásnál élőhelyrekonstrukció történt, így alkalmasnak tünik ehhez. NAGY PÉTER kérdések hiányában lezárta az előadoülést, és békés, boldog karácsonyt kívánt minden jelenlévőnek.

\section{3. előadóülés, 2018. február 3-án}

Ez az előadóülés az Akvaristák Magyarországi Egyesülete és az Állattani Szakosztály közös szervezésében megvalósult tematikus ülés volt, melyet NAGY PÉTER vezetett. Kifejezte újévi jókívánságait, majd megemlítette, hogy az előző ülés előadásai már megtekint- 
hetők a Társaság YouTube-csatornáján. Ezután néma felállással megemlékeztünk a közelmúltban elhunyt dr. MÉSZÁROS ZOLTÁNról és dr. PAPP JENŐről. NAGY PÉTER kiemelte, hogy az Akvaristák Egyesületét és a Szakosztályt FÜLÖP DÁVID hozta össze ezen tematikus ülés erejéig.

1. PASARÉTI GYULA: A hazai akvarisztika helyzete ma.

Az utóbbi 40 évben gyökeresen átalakult az akvarisztika. Elérhetővé váltak a külföldön megrendezett hatalmas, nemzetközi kiállítások. Nagyon sokat fejlődtek az eszközök, már az üvegtáblák is (színtelen táblákat sikerült előállítani), feltalálták a víz alatt is használható ragasztót. A szürők sokfélesége jelentősen nőtt, a világítástechnikában forradalmat hozott a LED. Az elérhető fajok száma is jelentősen nőtt, ennek köszönhetően specializálódni lehetett kisebb csoportokra. A kereskedelmi import nagyon sokat bővült, ám a személyes vadbefogás nagyon nehézkessé (engedélykötelessé) vált. Kereskedelmi cégek jöttek létre, melyek telephelyén millió liter nagyságrendü akvárium-térfogatban akár 1000-nél több fajt is tenyésztenek. Hazai viszonyok között 10 ezer liter víztől lehet gazdaságosan tenyészteni (akár kevés fajból sok példányt, akár több fajból kevesebb egyedet). Előadó a specializálódásra néhány példát hozott: egy celebeszi tórendszerben néhány éve igen dekoratív garnélákat fedeztek fel, ám ezeket eleinte nem tudták tartani, mert különleges vízkémiai viszonyokat igényeltek. Később egy aljzat kikísérletezésével megoldották e fajok tenyésztését, ám egyes példányaik még ma is több ezer dollárt érhetnek. Léteznek még - többek között - algaevő harcsákra specializált kereskedőcégek, páncélos harcsákat, ill. guppikat tenyésztő egyének is, de külön irányvonala van az aquakertészetnek (akváriumok berendezése növényekkel, mikrodomborzati elemekkel) is. A kiskereskedésekből Magyarországon az 1980-as, 1990-es években volt a legtöbb, azóta jelentősen csökkent a számuk; és a megmaradtak nagy része is nagykereskedésekkel áll viszonteladói kapcsolatban. A nagykereskedések viszont sokszor olyan példányokat hoznak be, amelyek egy éven belül elpusztulnak, így sosem telítődik a piac, és folyamatosan lesz kereslet az állataikra. A tenyésztök hiába árulnának sokkal jobb minőségü egyedeket, egyre kevesebb lehetőségük van eladni ezeket; az internet és a börzék (pl. TerraPlaza) jelentik számukra az esélyt. Az interneten igen gyorsan lehet információhoz jutni, ám erősen kérdéses ezek hitelessége, továbbá lassacskán elsorvasztja a nyomtatott szakirodalmat. Kapcsolati rendszereket lehet kiépíteni; értékesíteni lehet - bár az állatok vevőhöz történő eljutását nehezíti az a tény, hogy a posta élö állatot nem szállíthat. Ehhez az előadáshoz nem érkezett kérdés. ban.

2. LIZICZAI MÁRK: Veszélyeztetett diszhalak és fajmegőrző programok az akvarisztiká-

A díszhalakat veszélyeztető tényezők között első helyen kell említeni a klímaváltozást és ezzel összefüggésben az élőhelyek megváltozását. Súlyos károkat okoz a élőhelyek tönkretétele: a vízelvezetés és a környezetszennyezés, de a túlhalászat jelentősége sem elhanyagolható. Ez utóbbi föleg azon fajok állományait károsítja, melyeket nem éri meg tenyészteni (mert nehéz, vagy a piacokat már kisebb egyedszámban is telítik). Az idegenhonos fajok szintén veszélyeztetik az öshonos állományokat. A továbbiakban néhány szomorú példát hallhattunk az ember természetpusztításának hatásairól. Az ázsiai folyókat nemcsak a környezetszennyezés, hanem gátépítések is sújtják. A mexikói Cajititlan-tóból 112 tonna veszélyeztetett fogasponty pusztult ki egy súlyos szennyezés miatt. A Belo Monte projekt egy gátrendszer felépítését jelenti az amazóniai esőerdő szívében, amely nemcsak a folyómedret fogja átalakítani, veszélybe sodorva ezzel a Föld egyik leggazdagabb halfaunájú folyójának 
élővilágát, hanem az esőerdőből is nagy területet fog elárasztani. A Viktória-tó 500 körüli endemikus bölcsőszájúhal-fajainak nagyjából felét irtottuk ki; e fajszám az utóbbi 20 ezer évben alakult ki öt fajból, melyek egy nagymértékủ kiszáradás túlélöi voltak. Ezt a pusztulást a vízszint ingadozása (vízleeresztés), a vízszennyezés és az özönfajok (pl. vízijácint, nílusi sügér) túlszaporodása együttesen okozzák. Ezután az akvarisztikában nagy jelentőségü, veszélyeztetett halfajokat láthattunk, összesen 22 (fajtól a családig különböző rangú) taxonról esett szó. A törpe díszcsík jelenleg „csak” veszélyeztetett, de húsz éve még a kihaláshoz közel állt. Sajnos ellenpéldából jóval több akad; a közismert harcoshalak (Betta spp.) több faját már a kihalás fenyegeti. A közönséges kolibrihalat az akvarisztikában hatalmas mennyiségben tenyésztik, fillérekért beszerezhető, ugyanakkor a természetben már nagyon közel áll a kihaláshoz, esetleg ki is pusztult. A Stendhal-hal esete nagyon hasonló, természetes állományait sokáig kihaltnak tartották, ám öt éve megtalálták egy $10 \mathrm{~km}^{2}$-nyi területen. A magashegyi fogaspontyok (Goodeidae) már család-szinten veszélyeztetettek: mintegy 40 fajukból legfeljebb három olyan akad, melyeket ne fenyegetné semmilyen tényező. A nyomasztó információk után szerencsére kiderült, hogy reménysugarak is léteznek: az előadás utolsó részében nemzeti és nemzetközi fajmegörzési programok kerültek bemutatásra. Ezek egyrészt a fenyegetett fajok ex situ tenyésztésére, másrészt az eredeti élőhelyek megóvására helyezik a hangsúlyt, de sokuk az ismeretterjesztést, a szemléletformálást és a szakemberek közötti információáramlás, tapasztalatcsere segítését is fontosnak tartja. Több megőrzési programnak magyar magánszemélyek, szervezetek, sőt iskolák is tagjai. NAGY PÉTER javasolta Előadónak, hogy a magyar részvétellel folyó fajmegőrzési programokat érdemes lenne nagyobb nyilvánosság elött is bemutatni, és érdeklödött afelöl, hogy vannake ilyen terveik. Előadó elmondta, hogy az Akvárium magazinban folyamatosan közölnek a témába vágó írásokat. SZENDŐFI BALÁZS arra kérdezett rá, hogy in situ tenyészetek létrehozására van-e esély. Előadó válasza szerint Mexikóban léteznek ilyen programok, és bár a visszatelepítés sok esetben problémás, szerencsére sikerekre is vannak példák ezen a téren. Jelenleg azonban inkább stabil tenyésztett háttérpopulációk kialakítása az elsődleges cél. SZENDÖFI BALÁZS a távol-keleti viszonyokra is rákérdezett. Azt a választ kapta, hogy kevesebb fajmegörzési program müködik azon a vidéken - egyrészt azért, mert elég sok ottani veszélyeztetett fajból igen sok példány áll rendelkezésre a kereskedelem igényeit kiszolgáló tenyészeteknek köszönhetően, másrészt a távol-keleti országok sajnos nem próbálják meg helyreállítani a fajok élőhelyeit, így nem sok értelme lenne a visszatelepítéseknek.

3. SZENDÖFI BALÁZs: Inváziós és idegen halfajok természetesvizi honositása akvaristák által.

Előadó egy elgondolkodtató adattal kezdte előadását: a hazai élővizekben őshonos kb. 90 halfaj mellett már 60 idegenhonos faj példányait is megtalálták. Ezután az előadásban később elhangzó alapfogalmak tisztázása következett. Öshonosnak az a faj tekinthető, amely legalább kétezer éve jelen van az adott területen. Tájidegennek azt a fajt nevezzük, amely valamilyen hatást (pl. klímaváltozást) kihasználva olyan élőhelyekre kezdett átterjedni, ahol addig nem volt honos. Az idegenhonos faj fogalmát az Európai Parlament határozta meg néhány éve: olyan faj, amelyet távoli tájakról akaratlanul hurcoltak be vagy szándékosan telepítettek be. E kategória részhalmaza az invazív, vagyis az őshonosakra veszélyt jelentő faj. Az Európai Parlament kimondta, hogy az ember által okozott globális folyamatok közül az inváziós fajok terjesztése a legkevésbé visszafordítható. Filmrészletek lejátszásával folytatódott az előadás, amelyek a budapesti víztestekről és azok idegenhonos 
halairól szóltak. Az ezüstkárász képes szűznemzéssel szaporodni, így egyetlen nőstény is új állományt alapíthat; a stabilizálódott állományban aztán megjelennek a hímek. Mivel sok a klón, a betegségek igen gyorsan terjednek közöttük, ezekkel megfertőzhetik az öshonos fajokat. A törpeharcsa kedvenc tápláléka a halikra és a halivadék. Az amur válogatás nélkül legeli a víz alatt található növényi részeket. A kínai razbóra komoly sérüléseket képes okozni más halfajok egyedeinek (szem kicsipkedése, úszók letépése). A Városligeti-tó langyos vizü részén szinte csak idegenhonos halak élnek; főleg fogasponty fajok. A 11-es föút melletti kis csatornában tüskés pikók jelentek meg. A Duna köves parti sávját a torkolatvidékről feljött gébfajok foglalták el, gyors terjedésükben fejlett ivadékgondozásuk nagy szerepet játszik. A filmrészletek után tértünk rá az előadás címében megjelölt témára. A naphalat akvaristák telepítették be Nyugat-Európába. Innen 1905-ben került egy somogyi tógazdaságba, melyből szinte azonnal kijutott élővizeinkbe. Legnagyobb problémát agreszszív területfoglalása jelenti; ahol elszaporodik, ott egyedei a teljes parti sávot felosztják egymás között, és más fajokat egyáltalán nem engednek ide. A Kessler-gébet először Bécsnél találták meg a Dunában, valószínűleg akvaristák engedték bele. A Duna hazai szakaszáról már teljesen kiszorította az igen hasonló botos kölöntét. Az amurgéb a lápi pócot szorítja ki hasonló élőhelyigényével és életmódjával, ám kétszer akkora testméretével. Orosz természettudósok telepítették be Moszkva több tavába, onnan már akvaristák hozták KeletEurópába, ahonnan spontán terjedve jutott el hozzánk. Előadó ezen a ponton megkérdezte a hallgatóságot, hogy a jogi nehézségek ellenére foglalkozik-e valaki védett halfajaink mesterséges szaporításával. LIZICZAI MÁRK válaszolt: Vizsgálták a szivárványos ökle és a lápi póc tenyésztésének lehetőségét, ám éppen a jogi akadályok miatt kellett erről lemondaniuk. Előadó szerint a Szent István Egyetemen szaporítottak lápi pócokat, de csak több éves engedélyezési eljárás után tehették ezt. Előadó az akvaristákat igyekszik rábeszélni (nem védett) őshonos halfajok tartására. A kitérő után folytatódott a telepítések tárgyalása. Kiderült, hogy hazánkban ma az ezüstkárász a leggyakoribb halfaj. Budapest legnagyobb mocsarában ma csak aranyhal él (miután néhány éve kiszáradt), egészen biztos, hogy egy akvarista vagy kerti tavat birtokló lakos ,jóvoltából”. Sajnos léteznek olyan internetes fórumok, amelyekben azt tárgyalják, hogy mely meleg vizü forrásokba lehetne egzotikus állatot telepíteni - mondván, ott nem tesznek kárt, úgysem szöknek el onnan, de ha mégis, hamar elpusztulnak. Ezzel szemben egy fogasponty faj már itt-ott akklimatizálódott, ill. a Hévízi-tóba telepített bíborsügér pusztítja a csak ott őshonos hévízi ponty ivadékait. A Városligeti-tó kedvelt ,játszóterük" volt a felelőtlen akvaristáknak, dicsekedtek egymásnak azzal, hogy ki mit tett bele. A tó most nincs jó állapotban, és az előbb nevezett személyek már keresik az új telepítési helyszíneket... Az előadás vége felé a márványrák került terítékre. Szüznemzéssel szaporodik egész évben, már a békásmegyeri csatornában és egyéb budapesti patakokban is megvan. A három öshonos rákfajunkra most öt idegen faj jut, és évente újabbak várhatók - a tízlábú rákok a legreménytelenebb helyzetben lévő európai állatcsoport. Előadó zárszóként kiemelte legfontosabb üzeneteit: az akvaristák körében népszerüsíteni kellene őshonos halfajaink tartását, amelyhez megengedőbb jogi környezet lenne szükséges, és fel kellene hívni minél több ember figyelmét a felelötlen telepítések veszélyeire. TOMA IsTVÁN szeretett volna többet hallani a törpeharcsáról. Előadó gyerekkorában tartotta őket, a halörök ugyanúgy védték, mint más halakat. Az először idekerült fajt a később érkezett fekete törpeharcsa szorítja ki. Ez az újabb faj kisebb, élelmezésre még annyira sem alkalmas; nem árusíthatják, nem használhatják takarmányozási célra sem. TOMA ISTVÁN felvetette ezek után, hogy az ezüstkárász kártétele összemérhető a törpeharcsáéval. Előadó szerint az 
ezüstkárász még veszélyesebb is, mert a törpeharcsa mellett jobban megmaradnak más halfajok. NAGY PÉTER a filmfelvételek technikai hátterére kérdezett rá. Előadó víz alatti GoPro kamerát használt, és kameracsapdát is alkalmazott az álló helyzetű felvételeknél.

Az ülés végén NAGY PÉTER kiemelte, hogy a Szakosztály keretein belül minden előadó először tartott előadást, az akvarisztikai témájú közlemények számára publikálási lehetőséget ajánlott az Állattani Közlemények folyóiratban, végezetül szorgalmazta a civil szervezetek összefogását.

\section{4. előadóülés, 2018. március 7-én}

Az előadóülést NAGY PÉTER vezette le. Felhívta a hallgatóság figyelmét, hogy az ülésről videófelvétel készül, amely a YouTube-on megtekinthető lesz. Elmondta még, hogy a következő alkalommal a Botanikai Szakosztállyal közös tematikus ülést fognak tartani, ahol az épített környezetben végzett botanikai és zoológiai kutatásokról lesz szó

1. Horváth Gergely, Gonzalo Rodríguez Ruiz, José Martín, Pilar López és HERCZEG GÁBOR: A születést megelözö és azt követö környezeti eltérések hatása fiatal Iberolacerta cyreni gyikok viselkedési konzisztenciájára.

A viselkedési konzisztencia egy adott viselkedésben hosszú időn és sokféle ökológiai körülményeken át fennálló, egyedek közötti változatosságot jelent; állati személyiségnek is nevezik, amely nem állítható párhuzamba az emberi személyiséggel. Minden állatfajnál megfigyelhető. Jelenleg a viselkedésökológia egyik leginkább kutatott területe. A viselkedési változatosságot leggyakrabban egyedek közötti szinten szokás értelmezni, ám egyeden belül is lehet beszélni róla. Ez utóbbinak két formája van: a környezet által indukált változatosság, avagy viselkedési plaszticitás; és a környezettől független precízió, más néven viselkedési prediktabilitás. A viselkedési konzisztencia létrejöttének okairól sok elmélet látott napvilágot, pl. frekvenciafüggő szelekció tér- és időbeli eltérései, vagy a viselkedés állapotfüggősége. Sok adat szerint az egyedi állapot-eltérések, környezeti eltérések föleg az egyedfejlődés kezdetén hatva alakítanak ki stabil viselkedési konzisztenciát. Ugyanakkor a születés előtti hatásokat, pl. az anyai hatásokat, alig kutatták. Hüllőknél az anyai hatásokhoz tartozik a tojások inkubációjának minősége, de a tojások létrehozása közben az anyát ért hatások is. A bemutatott kutatásban a $\mathrm{D}_{3}$ vitamin hatásait vizsgálták. Egyes adatok szerint az embrió fejlődésében fontos szerepe van, amellett, hogy az egészséges csontozat kialakításához nélkülözhetetlen. Szerzők keresték a választ arra a kérdésre, hogy az anya $\mathrm{D}_{3}$ vitamin-szintje és a születést követő stressz hat-e az utód viselkedési konzisztenciájára, az egyed viselkedési típusára és a viselkedés prediktabilitására. Az utódokat négy csoportra osztották: az egyikben csak kortikoszteront (stresszhormon) kaptak, a másik csoport anyja D-vitamint kapott (az utódok stresszhormont nem), a harmadikban ök maguk kortikoszteront, valamint anyjuk D-viamint kaptak, végül a kontroll csoportban sem ök, sem anyjuk nem kaptak e vegyületekböl. A hormont és a vitamint táplálékkal vették magukhoz. Eredményeik a következők voltak: (1) a vitamint kapott anyák utódai jobb motoros képességekkel rendelkeztek (gyorsabban másztak függőleges felületen), (2) a vitaminos anyák utódai kockázatvállalóbbak voltak, (3) a stresszhormont kapott utódok többet rejtőztek el, (3) a vitaminos anyák utódainak viselkedése sokkal kiszámíthatóbb volt, (4) a nem-vitaminos 
anyák stresszhormont kapott utódainak viselkedése volt a legkevésbé megjósolható. Mindezek alapján elmondható, hogy az anyai táplálék minősége potenciálisan befolyásolja az utódok rátermettségét és viselkedését, az egyedek közti viselkedési különbségek egy hatásra el is tünhetnek, és a stressznek viselkedési stratégiára gyakorolt befolyása az anyai hatásoktól függ. BAKONYI GÁBOR arról érdeklődött, hogy létezik-e szempontrendszer annak eldöntésére, hogy mikortól számít egy adott viselkedésforma konzisztensnek, mennyi időn belül, hányszor kell ismétlődnie. Előadó szerint ez aktuális kérdés, nincs rá egzakt válasz, de mindenképp több héten, akár több hónapon át kell vizsgálni az egyed viselkedését. BAKONYI GÁBOR: Az aktuális kísérletben mi a helyzet? HORVÁTH GERGELY: Egy hetes utódokat követtek nyomon két héten át, naponta mérték viselkedésüket; egy napon belül többször nem érdemes. NAGY ZSOLT arra kérdezett rá, hogy pontosan hogyan zajlik egy ilyen kockázatvállalási vizsgálat. Előadó válasza: Általában előbújási látenciát szoktak mérni (mennyi idő múlva jön elő búvóhelyéről egy behatás után), ám az aktuális kísérletben lefagyási látenciát mértek - idegen környezetbe helyezés után azt mérték, mennyi idő múlva tér vissza a szokásos aktivitás. FóNAGY ADRIENN arra volt kíváncsi, hogy a napszaknak nem lehet-e jelentősége a vizsgálatok során. Előadó egy másik kísérletben ezt is vizsgálta, de még nem elemezte eredményeit; a jelen vizsgálathoz az adatgyüjtést mindig azonos napszakban végezte. NAGY PÉTER ajánlotta az Állattani Közlemények folyóiratot az eredmények publikálásához.

2. BAKONYI GÁbOR, SERES ANIKó és SzABÓ BorbÁLA: Növényvédöszeres kezelések generációkon átivelö hatásai: epigenetika az ökotoxikológiában.

Előadó rövid történeti áttekintéssel vezette be mondandóját. LAMARCK azt vallotta, hogy az a szerv, amely fokozott használatnak van kitéve, fejlettebbé válik, és ebben az állapotában öröklődik. Ez a feltételezett mechanizmus emlékeztethet az epigenetikus öröklődés mechanizmusára. Előadó fiatal korában a lamarcki elméletet hangsúlyozták, mert az akkoriban általánosan elhitt MICSURIN- és LISZENKO-féle tanok (melyek a genetika törvényszerüségeit teljesen elutasították) részben erre épültek. Még a DNS szerkezetét bemutató 1953as közlemény előtt alkotta meg úttörő elméletét WADDINGTON, és ezzel az epigenetika úttörỏjévé vált: a környezet szabja meg, hogy egy multipotens sejtből milyen irányba specializálódott sejt jön létre. Ha a környezet nagy stresszhatást gyakorol, akkor megváltozik a fenotípus, és ez fog öröklödni. Epigenetikai változást sokféle tényezö kiválthat, többük igen jelentös az ökotoxikológiában; ezek közül Előadók a xenobiotikumok hatását vizsgálták ugróvillásokon; a szülőknek xenobiotikumot adtak, majd utódaik fele szintén kapott ilyen anyagot, fele nem. Nézték a szülők és utódok szaporodását, az RNS és különböző fehérjéik szintjét. Azt tapasztalták, hogy a xenobiotikum-koncentráció növelésével csökkent a szülők utódainak száma, és nőtt a Hsp70 (stresszfehérje)-kifejeződés mértéke. Ezek várható eredmények voltak, ám a nem kezelt F1-egyedeknél ugyanilyen hatást találtak, ami már meglepő volt. Előadók ezen a ponton azt feltételezték, hogy a kezelés a szülők ivarsejtjeire is hatott. Az F2-nemzedékben már elmúlt az utódszámra gyakorolt hatás, viszont a Hsp70kifejeződés továbbra is magas maradt. A xenobiotikumnak ivarsejtre gyakorolt közvetlen hatása itt már kizárható volt, vagyis epigenetikus öröklődés kialakulását sikerült megfigyelni. Az epigenetikai változások mechanizmusa lehet a DNS metilációja, vagy a hisztonfehérjék módosítása, ám azt, hogy ezek pontosan hogyan fejtik ki hatásukat a gének kifejeződésére, még kutatni kell. Jelen vizsgálatban Előadók ilyen részletek felderítésére nem vállalkoztak, mindössze a transzkripciós hatásokat vizsgálták. NAGY PÉTER megje- 
gyezte, hogy bőven van még kutatnivaló, és sok sikert kívánt a vizsgálatok folytatásához. VÁSÁRHELYI TAMÁS felhívta a figyelmet a közelgő Beporzók Napjára, amely arra szeretné felhívni széles néprétegek figyelmét, hogy csökken a rovarok egyedszáma. Sok egyesület támogatja ezt a kezdeményezést, az első alkalomnak a Magyar Természettudományi Múzeum Ludovika kiállítási épülete fog otthont adni.

1045. előadóülés, 2018. április 25-én

közös előadóülés a Magyar Biológiai Társaság Botanikai

Szakosztályának 1488. szakülésével

Ezt az előadóülést a Botanikai Szakosztállyal közösen tartottuk, melynek témája „Botanikai és zoológiai kutatások épített környezetünkben” volt. Az ülést ezúttal CsONTOS PÉTER, a Botanikai Szakosztály elnöke vezette. A növénytani témájú előadások rövid kivonatai a Botanikai Közlemények 2018. évi 105. kötete 2. füzetében olvashatók.

1. Hargitai Rita, NAGy Gergely, NyiRi Zoltán, Eke ZsuZSANNA és TÖRÖK JÁNOS: A városi környezet hatása a széncinege tojásának jellemzöire.

A városokban sok zavaró antropogén hatással kell szembenézniük a madaraknak, melyek közül igen jelentős a szennyező anyagoknak a szervezetükbe kerülése. Ez a táplálékláncon át történik, és a madarak szervezetét többek között az ürülékbe kiválasztva hagyhatják el. Különböző anyagok fokozzák az oxidatív stresszt, amely befolyásolja a tojásba jutó antioxidánsok mennyiségét. A szennyező anyagok elvékonyíthatják a tojáshéjat, és a protoporfirin-szint befolyásolásával megváltoztathatják a tojáshéjak mintázatát. Előadók jelen vizsgálatának célja volt, hogy egy-egy városi és erdei (Visegrádi-hg.) széncinegepopulációt hasonlítsanak össze tojásaik szennyezőanyag-koncentrációja, kalciumszintje és alaktani jellemzőik alapján. Minden vizsgált fészekaljból egy-egy tojást gyüjtöttek be, emellett a madárpopulációk élőhelyének talaját is vizsgálták. A következő eredmények születtek: A városi talajban az arzén, a réz, a nikkel és a cink koncentrációja magasabb volt, mint az erdei talajban. A városi tojáshéjak ólomszintje sokkal magasabb volt, mint az erdőben keltetett tojások héjában, ugyanakkor a réz és a cink koncentrációja nagyjából megegyezett a két helyszínen. Kadmiumot, nikkelt és arzént egyik tojás héjában sem tudtak kimutatni. A városi és erdei tojások méretében és színezetében nem találtak számottevő különbséget, de a városi tojások héja vastagabb volt, mint az erdeieké. Egyes antioxidánsok (lutein, retinol) szintje az erdei, másoké (tokoferol) pedig a városi tojásokban volt magasabb. A diszkussziónál Előadó megemlítette, hogy hiába volt a városi talaj ólomkoncentrációja jóval magasabb az erdei talajnál, ez még mindig alacsonyabb annál, mint ami más városi helyszíneken tapasztalható. A városi talaj kalciumszintje magasabb volt az erdei talajnál; ennek oka az lehet, hogy vulkanikus eredetű hegységben helyezkedett el a vizsgált erdei populáció és a talaj. Az antioxidánsokat általában táplálékkal veszik fel a cinegék (föként lepkehernyókból), amelyböl az erdőben többet találnak, mint a városban. A tokoferol szintje viszont azért lehet magasabb a városi tojásokban az erdeiekhez képest, mert a szülő ezzel az antioxidánssal próbálhatta kompenzálni a többi antioxidáns alacsony szintjét. SZIRÁKI GYÖRGY egy pontatlanságra mutatott rá: Elöadó eredetileg a Pilist említette az erdei terület helyszíneként, viszont az a hegység nem vulkanikus kőzetből épül fel. Majd kérdését is feltette: Vizsgálták-e a szelén koncentrációját, ugyanis ez az embereknél fontos 
nyomelem, és a táplálékunkban megjelenő koncentrációját a talaj befolyásolja. Előadó a helyreigazítást megköszönte és elmondta, hogy vizsgálták a szelén szintjét is, de nem mutatott eltérést a két helyszín talaja között. CSONTOS PÉTER elnök úr Előadó védelmében megjegyezte, hogy még turistatérképen is előfordul a Pilis és a Visegrádi-hegység neveinek öszszekeverése, és afelől érdeklődött, hogy a régi tojásgyüjtemények felhasználhatók-e ilyen kutatásokhoz. Előadó szerint a héjmintázat vizsgálatához használhatók. CsORBA GÁBOR kérdése arra vonatkozott, hogy a vizsgált tojásból lesz-e még fióka. Előadó válasza: Nem lesz, bár érdemes lenne a fiókákat is vizsgálni. A kutatás során azzal a feltételezéssel éltek, hogy adott fészekalj többi tojásának is olyan tulajdonságai voltak, mint a vizsgált tojásnak.

2. TAMÁS JÚLIA, CSONTOS PÉTER és VIDA GÁBOR: Épitett falak spontán páfrányflórája: tömeges és különleges elöfordulások.

Az előadás rövid kivonata a Botanikai Közlemények 2018. évi 105. kötete 2. füzetében olvasható.

3. SzINETÁR CSABA és KovÁCS GÁBOR: Álkaszások (Pholcidae) és álfarkasok (Zoropsidae), elmaradhatatlan albérlöink.

Az előadás két részből állt. Először áttekintést hallhattunk az emberrel együtt élő pókfajok kutatásának történetéről, csoportosításáról és a jövőben várható terjedésükröl, majd a fajok részletesebb bemutatása következett. Kifejezetten a városlakó pókokat hatvan éve vizsgálták először, majd az 1980-as években Németországban szaporodtak el az ilyen témájú kutatások. A városlakó pókok származásuk szerint lehetnek euszinantrópok vagy hemiszinantrópok. Euszinantrópnak azokat a fajokat nevezzük, amelyeknek adott helyen nincs populációjuk a természetben, ezek az idegenhonos fajok közül kerülnek ki. Európába eddig 165 ilyen pókfaj került be, melyeknek nagyjából harmada honosodott meg, a megtelepedett fajok zömmel Ázsiából származnak. Ugyanakkor dél-európai fajok is viselkedhetnek más területen euszinantrópként. Hemiszinantróp fajok pedig azok, amelyeknek nemcsak az ember közelében, hanem a természetben is van populációja. A jövőben várható újabb fajok betelepülése, ám ez a folyamat nem lesz túl látványos. A klímaváltozás következtében a szinantróp fajok ki fognak költözni a szabad ég alá, a házak falára vagy az udvarokra. A családi házak faunája változatosabb, mint a panellakásoké. Az előadás következő részében összesen 11 pókfajjal ismertette meg Előadó a hallgatóságot. Megtudtuk, hogy a nagy álkaszáspók már elkezdett kiköltözni, és hogy családjának már hat faja fordul elő hazánkban. A csupaszpók (Scytodes thoracica) csinos, borostyánszínű alapon fekete mintás állat. A tüskéskezü álfarkaspók (Zoropsis spinimana) cselőpók méretü, ezért várhatóan sok ijedséget fog okozni a laikusok között. A veszélyes mérgü banánpók rendszertelenül érkezik gyümölcsszállítmányokkal, de nagyon ritkán fekete özvegy fajok (Latrodectus spp.) egyedeit is behurcolják véletlenül. Mindazonáltal veszélyes fajok nem fognak megtelepedni nálunk. TÓTH MÁRIA az előadás végét követően azt a kérdést vetette fel, hogy létezik-e épületben lakó rovarra specializálódott pókfaj. Előadó válasza alapján nincs ilyen; a behúzódó poloskákat a házi pókok csak végső esetben fogyasztják, nem szeretik. A bogarakat nem ejtik zsákmányul, de a molyokat igen, és a többi, lakásban élő pókot is elfogyasztják, ha tehetik. Ne várjuk tölük a bejutott rovarok látványos ritkítását. A következő kérdést BÖHM ÉvA intézte Előadóhoz. Nem örül annak, hogy az álkaszáspókok szeretnek a fürdőszobájában tartózkodni, és e viselkedés okát szerette volna megtudni. Előadó azt tanácsolta, hogy addig örüljünk, amíg velünk vannak ezek az állatok. CSECSERITS ANIKÓ arra volt kíváncsi, hogyan terjednek a pókok épületröl-épületre. A válasz szerint főleg légi úton, fona- 
lat eresztve, néhány faj pedig szállítmányokkal. CSONTOS PÉTER arról kérdezte Előadót, hogy mekkora földrajzi léptékben kell érteni azt, hogy egy pók euszinantróp. Előadó szerint mindig csak az adott földrajzi helyre vonatkozik a megjelölés; nem ismerünk olyan fajt, amely az egész Földön csak házakban élne.

4. KöRMÖCZI LÁsZLÓ, KIsS PÉTER JÁNOS, ÁCS ANITA és BozÓKI VIKTÓRIA: Nagyvárosi zöldhálózat: a regionális flóra kapcsolata a belvárossal.

Az előadás rövid kivonata a Botanikai Közlemények 2018. évi 105. kötete 2. füzetében olvasható.

5. BOLDOGH SÁNDOR ANDRÁs: Denevérek az épittett környezetben - új kutatási és védelmi kihívások

Már középkori írott források is említenek templomtornyokban lakó denevéreket. Azóta elterjedésük észak felé tolódott, amit emberi hatások gyorsítottak. A denevér fajok drasztikus állománycsökkenést szenvedtek el, ám ennek a ténynek a felismerése hosszú ideig tartott - ennek oka rejtett életmódjuk és nehéz vizsgálhatóságuk lehet. Mindemellett sok negatív elöítélet él irántuk a laikusok között. Mivel csoportosan élnek, a károsító hatások egyszerre sok egyedet érintenek. A fényszennyezésnek különösen kitett élőlénycsoport. Annak ellenére, hogy néhány fajuk épületekben is megtelepedhet, nem urbanizálódtak. A patkósdenevérek eléggé érzékenyek, természetes búvóhelyeik a barlangok voltak. A hazai denevérkutatás a klímaváltozás és a fényszennyezés denevérekre gyakorolt hatásait, az állatok vonzáskörzetét és hatósugarát, valamint a betelepítés, áttelepítés lehetöségeit öleli fel. Ezek mellett védelmi programok indultak, és megkezdödött a nagyközönség szemléletformálása is. A globális melegedés miatt déli fajok honosodnak meg nálunk, de a hőhullámok károsak a denevérekre, akár több százas elhullásokat is okozhatnak! A jövőben sajnos a höhullámok fokozódása várható. A denevérek érdekében lehet hüteni a házakat, vagy biztonságosabb lakóhelyre lehet átirányítani az állatokat. A fényszennyezés első látásra még jó is lehetne számukra, mert a fényre gyült rovarok könnyü zsákmányt jelenthetnek, viszont a fény megzavarja a denevérek bioritmusát: később kezdik vadászatukat, ám akkor már jóval kevesebb rovart találnak. E problémának a megoldása egyszerünek tünhet, hiszen csak le kellene kapcsolni az utcai lámpákat. A hatósugár és vonzáskörzet kutatásában azt találták, hogy akár $28 \mathrm{~km}$-re is eltávolodhatnak egy éjszaka alatt (nyomkövetővel láttak el egyedeket). A populációk felosztják egymás közt a területeket. Áttelepíteni nem lehet a denevéreket, mert vagy visszajönnek eredeti élőhelyükre, vagy elpusztulnak. A templomokat próbálják denevérbaráttá tenni: átfestik a tetőket, a világítást optimalizálják a denevérek igényei szerint, és szemléletformálást is végeznek: lelkészi találkozókon és más klerikális összejöveteleken tartanak előadásokat. TóTH MÁRIA érdekesnek tartotta, hogy a fényszennyezés ennyire megváltoztatja a denevérek aktivitását, mert a nap viszonylag kevéssé zavarja öket. Előadó szerint összetett kérdéskörről van szó, pl. a patkósorrúak nagyon érzékenyek. TóTH MÁRIA: A denevérodúkat milyen számban érdemes kihelyezni? BOLDOGH SÁNDOR: A valaha barlangban élt, ill. most is ott lakó fajok nem fognak átszokni az odúkra.

6. Matus Gábor, Freytag CSONGor, Varga Zoltán, Mészáros Ilona, Adorján

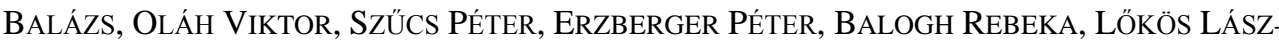
LÓ és FARKAS EDIT: Vigyázat, a botanikusok a tetön dolgoznak!

Az előadás rövid kivonata a Botanikai Közlemények 2018. évi 105. kötete 2. füzetében olvasható. 


\section{6. előadóülés, 2018. május 9-én}

Az előadóülés megnyitásaként NAGY PÉTER elnök úr elmondta, hogy a Szakosztályban választást tartottak, melynek során a Választmányban kisebb személyi változások történtek. Megemlítette azt is, hogy a Társaságban is történt tisztújítás; új elnököt, elnökhelyetteseket, fötitkárt és fötitkárhelyetteseket választottak.

\section{CZIGÁNY ILDIKÓ: Madarak pilótaszemmel.}

Előadó az előadást a madarak és az emberi repülés világa közé húzott párhuzamokra építette fel, saját szakmai életútjától kezdve. A repülés mellett az írás is mindig része volt Előadó életének, saját könyveiből el is hozta a madarakhoz kapcsolódó müveket, és ejtett róluk néhány szót. Vadgazdálkodást tanult, már főállású pilótaként, de dolgozott a Fővárosi Állatkert madármentő állomásán, és asszisztens is volt egy állatorvos (papagájdoktor) mellett. Jelenleg egy alapítvány elnöke. A madár mindig is szimbólum volt, álmában gyerekként szinte mindenki szeretett volna madár lenni, mert sok tulajdonságukért irigyeljük őket: színeikért, hangjukért, és persze a repülésért. A madarak és repülőgépek szárnyán is felhajtóerő keletkezik a különleges szárnyprofil miatt, ám a madarak szárnya sokkal kifinomultabb, alakja jobban változtatható, mint a repülőgépeké. Gyorsan emészthető, gyorsan felszabadítható energiájú táplálékot kell magukhoz venniük. A repülőgépek navigációja csak az utóbbi időben vált függetlenné külső eszközöktől, pl. rádióadóktól: már lézeres giroszkópok jeleznek bármilyen irányú és mértékü elmozdulást egy referenciaponttól, és ezeket összegezve adják meg a gép helyét. A madarak földmágnesesség-alapú navigációja jelenleg is intenzív kutatások tárgya. Az utasszállító repülőgépek átlagos utazómagasságában is előfordulnak madarak: ludak és keselyük. A madaraknál és repülőgépeknél egyaránt fontos a kommunikáció, mely föleg hangokkal történik. Az előadás vége felé állatvédelmi, állatjóléti témák is szóba kerültek, majd Előadó egy könyvéböl olvasott fel részletet. Ezt azzal a mondattal zárta, amelynek mondanivalója az egész előadás alatt érezhető volt: „Nincs pilóta, akire jobban felnéznék, mint rájuk!’Az előadás után nem hangzott el kérdés.

2. BozÓ LÁSZLÓ, HeIM WIELAND és CSÖRGÖ TIBOR: Következtethetünk-e a szibériai poszátafélék Európába történö kóborlásának okaira azok vonulás-dinamikájának vizsgálatával?

Az utóbbi évtizedekben számos szibériai madárfaj jelent meg Európában: parti madarak és különféle énekesek. Főleg ott történnek észlelések, ahol fejlett felszerelésük van a megfigyelőknek - hazánkban az elérhető technika fejlődésével az ilyen megfigyelések száma is nő; már 16 szibériai madárfajnak van legalább egy magyarországi adata. Átlagosan évente egy új fajt figyelnek meg annak ellenére, hogy komoly földrajzi barrier (a Kárpátok) veszi körbe hazánkat. Egy korábbi elképzelés szerint a szibériai fajok a megszokottal éppen ellentétes irányba indulnak el vonuláskor (reverse migration), így jutnak el Európába. A Britszigeteken tett megfigyelések illeszkednek ebbe az elméletbe: az észak-szibériai fajok inkább a szigetek északi, míg a dél-szibériaiak inkább a déli területein bukkannak fel. Ellenérvek is léteznek: a hibás orientációjú egyedeknek ki kellene szelektálódniuk, ezzel szemben a számuk évről-évre nő. Talán inkább a fiatal madarak diszperzióját figyelhetjük meg; kirepülés után bármely irányba kóborolhatnak, ám Nyugat-Európában találkoznak a legbarátságosabb környezettel (és nem mellesleg a legtöbb madarásszal). Elképzelhető az is, hogy a most kóborlónak tekintett egyedek mintegy „előörsei” egy, a jövőben kialakuló szabályos vonulásnak, és ezek a fajok idővel szabályos telelöterületként fogják használni 
Európát is (,álkóborlók”). Úgy tünik, hogy az időjárási körülmények (Szibéria fölött gyakran kialakuló folyamatos keleti szél) nem befolyásolják a madáregyedek vonulási irányát, viszont orientációjukat megzavarhatja az, hogy Szibéria egyes vidékein a földmágnesesség anomáliákat mutat. Általános magyarázat nincs, valószínűleg mindegyik hipotézisben van több-kevesebb igazság. További kutatások szükségesek, amit viszont nehezít a gyürüzőállomások roppant alacsony száma. Előadó kutatási területe az Amur folyónál, Kína és Oroszország távol-keleti határvidékén volt (Muraviovka Park), egy mocsaras-nádasosbokros területen. Változékony időjárású vidék, hőmérsékleti és csapadékbeli szélsőségekkel. Gyürüzték 11 vizsgált faj több mint 10 ezer egyedét; mintegy 1800 visszafogással. Megpróbáltak a kapott adatokból az európai kóborlások okaira következtetni: a vonulási fenológiát leírták és más gyürüzőállomások adataival összevetették, továbbá elemezték az időjárási események vonulásra gyakorolt hatását. Több fajnál ivar szerint elkülönült vonulást találtak: a hímek előbb érkeznek és később mennek el, mint a nőstények. Tavasszal a hőmérséklet, ősszel inkább a szél és a csapadék tulajdonságai voltak a legfontosabbak. Értékelésként megállapítható, hogy a ritkább fajok Európába jutásában fontos lehet a folyamatos keleti szél. Más fajoknál a diszperzió tünik a legfontosabbnak, míg olyan fajokat is találtak, ahol a reverz vonulás is számításba jöhet. Két fajnak még nincs európai adata, ezeknek van a legkeletibb elterjedési területük. Összel az időjárás jobban befolyásolta a vonulást, mint tavasszal; tavasszal nem sok választásuk van a madaraknak, mindenképp vonulniuk kell. SZÖVÉNYI GERGELY: Ezek szerint kevés az ismeret a szibériai pontos vonulási útvonalakról? Bozó LÁszLó: Nagyon kevés a visszafogás, mert igen kevés a gyürüzőállomás. A telelőterületekről sem tudunk szinte semmit. Nagyon nehéz bármilyen kutatást szervezni, mert még a helyi egyetemek sem foglalkoznak vonuláskutatással. SZÖVÉNYI GERGELY: Folynak-e geolokátoros kutatások? BOZÓ LÁsZLÓ: Igen, de éppen a geolokátorozott fajokból még nem volt visszafogás, pedig a gyüjtött adatokat csak így lehetne kinyerni. NAGY PÉTER afelöl érdeklődött, hogy az adatok kis száma ellenére látszik-e esetleg a klímaváltozásnak a telelöterületeket és vonulási útvonalakat módosító hatása. Elöadó szerint túl kevés az adat ennek kimutatására. NAGY PÉTER: Az extrém helyszínekre kóborolt egyedeket visszafogták-e eredeti elterjedési területükön? Bozó LÁszLÓ: Nincs ilyen adat. NAGY PÉTER szerint bőven vannak még kihívások, és sok sikert kívánt a kutatás folytatásához. Kiemelte, hogy CZIGÁNY ILDIKÓ és BOZÓ LÁsZLÓ is először tartottak elöadást a Szakosztályban.

\section{AgÓCS JULIANNA és CSÖRGÖ TIBOR: Extrém vonulási utak a madárvilágban}

Előadó BSc hallgató, arra vállalkozott, hogy összeszedje a madarak legnagyobb vonulási teljesítményeit és az ezeket nehezítő tényezőket. A tengereken történő átkelés az ilyen vonulások gyakori eleme; pihenő- és táplálkozóhelyek, valamint tájékozódási támpontok nélkül, ugyanakkor kiszámíthatatlan időjárási viszonyokkal. Zsírraktár és a megfelelő szélirány nélkülözhetetlen egy ilyen úthoz. Az észak-atlanti vonulók Észak-Amerikából DélAmerikába tartanak az Atlanti-óceán fölött, esetleg Európából Grönlandra (hantmadár). A Csendes-óceán felett vonul a tahiti póling (Alaszkától Hawaii-ig) és a kis goda keleti alfaja (Alaszkából Új-Zélandra - több mint 10 ezer km). Utóbbi faj indulás előtt megduplázza testtömegét, és az út során optimalizálja belső szervei működését (tápcsatornája kismértékben veszít térfogatából, míg a repüléshez és méregtelenítéshez szükséges szervek kissé megnagyobbodnak). A tavaszi visszaút Korea érintésével történik. A csúcstartó a sarki csér, amely az Atlanti-óceánt szeli át hosszában évente kétszer, minden évben kb. 64000 km-t 
megtéve (átlagosan harminc évig él). Vonulásának mintázata nagymértékben átfed a légkörzés mintázatával. A sivatagok felett is zajlanak vonulások, ahol a nagy napi hőingás és az alacsony páratartalom is nehezítő tényezö; a tengereknél látottakon túl. Hazai vonuló fajaink nagy része a Szaharát szeli át, és még elötte a Földközi-tengert is. A Száhel-övezet ősszel táplálékot nyújt, ám a tavaszi vonulás során száraz, ezért a tavaszi vonulás útvonala hosszabb az őszinél. A magashegységek eltérő kihívások elé állítják a vonuló madarakat: nagy magasságot kell elérniük, ami sok energiát igényel, és ott extrém hideg uralkodik. Így viszont nagy kerülöt spórolnak meg, és a jet stream áramlások hátán nagy sebességre tesznek szert. Az indiai lúd a Himalája felett $8 \mathrm{~km}$-es magasságban, $-50^{\circ} \mathrm{C}$-os hőmérsékleten repül át; ehhez a keringési rendszere révén adaptálódott. A pártásdarunak nemcsak a Himaláján, hanem a Góbi-sivatagon is át kell kelnie, a kedvezőtlen irányú szelek ellenére. Sok parti madár a tengeri jég felett vonul. A tengerek jelentette nehézségeken túl a hideggel is meg kell küzdeniük az erre vonuló fajoknak. A laposcsőrü víztaposó a Shetland-szigetektől Észak-Amerikáig tengeri jég fölött vonul, de útját Peru környékéig folytatja. Az előadás után CZIGÁNY ILDIKÓ megköszönte, hogy meghallgatta ezeket az előadásokat, sokat tanult belölük. NAGY PÉTER gratulált Előadónak a magas színvonalú, sok irodalmazást igénylő előadásához és sok sikert kívánt további kutatásaihoz. Az előadóülést a nyári időszakra vonatkozó jókívánságaival és az októberi viszontlátás reményének kifejezésével zárta le.

\section{7. előadóülés, 2018. október 3-án}

NAGY PÉTER elnök úr, az előadóülés levezető elnöke arról számolt be, hogy az ülés minden előadója először tart előadást a Szakosztályban.

1. BeCZ BARNABÁS Álmos és TÖRÖK JÚLIA: Mikroszkopikus erdők a Dunában: a Ráckevei-Duna élöbevonatairól.

Irodalmi adatok alapján az új felületek benépesülése során a heterotróf ostorosok szaporodnak fel a leggyorsabban, de aztán az egyedszámcsökkenésük is viszonylag gyors. A felületeken (pl. nádlevélen) élő harangállatkák egész kis életközösségnek adnak otthont, többek között napállatkák és szájkoszorús csillósok is megtalálhatók testfelületükön. Szerzők a Ráckevei-Duna vizébe tárgylemezeket merítettek, és különböző időtartamok után vizsgálták, hogy milyen élőlények telepedtek meg rajtuk. Az első napon már sok heterotróf ostorost találtak, melyek törmelékfelhőt alkottak; rajtuk kívül megjelentek már ragadozó csillósok és szájkoszorús csillósok is. A második nap legjellemzőbb változása a nagyobb törmelékfelhők megjelenése volt. A harmadik napon új taxonokkal bővült a biofilm élővilága: járólábacskás csillósok, Euglena ostorosok és Stentor kürtállatkák jelentek meg. Az ötödik napon észleltek először szaporítóképleteket, valamint a szájkoszorús csillósok ragadozóit; végül a hatodik napon az élősködők is előkerültek. Előadó az eredményeik ismertetése után összefoglalta a Rajnában található élőbevonatok kutatásának irodalom által említett eredményeit. Abban a folyóban egész évben a szájkoszorús csillósok dominálnak; ezek telepeiben folyamatos vízáramlás figyelhető meg. A szájkoszorús csillósok „lombkoronaanalóg" szerepet töltenek be a mikroszkopikus erdőben; különböző részeiken más-más élölények telepednek meg. Száruk alsó szakaszán harangállatkák, a középső szakaszon apró szájkoszorús csillósok, míg felül kovamoszatok figyelhetők meg. A „lombkoronában” galléros-ostorosok élnek. Gyakran teljesen eltűnik pár nap alatt az összes kolonizáló faj. Az 
egyik csillós faj, a Zoothamnium kentii élőbevonata máig ismeretlen. SZIRÁKI GYÖRGY gratulált Előadónak az idegenvezetéshez, majd megkérdezte, hogy a vizsgálatot a RáckeveiDuna mely szakaszán végezte, és hány tárgylemezt használt. Előadó Szigetszentmiklós régi hajókikötőjében hajtotta végre kutatását, mindegyik időintervallumban egy-egy tárgylemezt kolonizáltatott. Célja egy fajlista összeállítása volt. SZIRÁKI GYÖRGY: A Ráckevei-Duna nem egészen holtág! A fö sodorvonalban folyamatosan mozog a víz, ám az tény, hogy vannak áramlásmentes oldalágak („,hókonyok”). A Rajna más dinamikájú, ezért nehézkes a két folyó összehasonlítása. BECZ BARNABÁs: Azért a Rajnával hasonlították össze az élőbevonatot, mert szinte csak azon a folyón történtek eddig ilyen témájú kutatások. SzIRÁKI GYÖRGY végül jó munkát kívánt. NAGY PÉTER hasonló jókívánságait fejezte ki, és jótanácsként megjegyezte, hogy ha konferencián is szeretné bemutatni Előadó ezt a kutatást, akkor a vizsgálati paramétereket pontosabban kell majd megadni.

2. GYÖRGY AleXANDRA, BORZA PÉTER és TÖRÖK JÚLIA: Invázió a Lágymányosiöbölben - A makroszkopikus gerinctelenek felmérésének eredményei.

Az előadás a Lágymányosi-öböl helytörténetének összefoglalásával kezdődött. Az 1838-as nagy árvíz után született meg a Duna szabályozásának igénye, és a munkálatok során választották le a Lágymányosi-öblöt egy hosszú gáttal. Később az öböl nagy részét feltöltötték (jelen előadóülésnek otthont adó épület is a feltöltött területen épült). Az inváziós fajok kutatása igen hasznos, mert ezek a fajok számos negatív hatást gyakorolnak az öshonos élővilágra; többek között új betegségeket hoznak, vagy kiszorítják az őshonos fajokat. A vízi mütárgyak rongálásával közvetlen gazdasági kárt is okoznak. Szerzők célul tủzték ki a Lágymányosi-öböl bentikus makrogerinctelen-faunájának felmérését, és tapasztalatokat szerettek volna nyerni egy saját készítésủ gyüjtőeszköz, egy szán használhatóságáról, melyet a partról lehet vontatni, és fenékről gyüjt anyagot. Az öbölben három helyszínt vizsgáltak: az iszapos aljzatú áramló vízzel jellemezhető torkolati szakaszt, a főleg kavicsos, lassabban áramló vizü középső szakaszt, és az áramlást nem mutató, főleg homokos aljzatú belső szakaszt. A gyüjtések 2017. májusától szeptemberéig, 17 alkalommal zajlottak. Minden alkalommal minden helyszínen három ismétlést végeztek, egyszerre legalább két fő részvételével. A begyüjtött anyagot iszapolták, kisózták és konzerválták, a válogatás laboratóriumi körülmények között zajlott. A legtöbb példányt faji szintig képesek voltak meghatározni. A puhatestü fajok zömének csak a torkolati szakaszon találták élő egyedeit (házak, héjak máshol is voltak). A középső szakaszon szivacstelepre bukkantak. A legszegényesebb faunát a belső szakasz mutatta. Találtak egy, erre a folyószakaszra új hasadtlábú rák (Mysida) fajt. A felemáslábú rákokat (Amphipoda) kizárólag idegenhonos fajok képviselték. Eredményeiket egy romániai Duna-szakaszról szóló 2012-es kutatással összevetve kevesebb őshonos fajt találtak, és más idegen fajok kerültek elö. Összességében elmondható, hogy a Lágymányosi-öbölben már csak maradványa van meg a természetes faunának. Az általuk készített szán jól használható, ám még nem kiforrott: sérülékeny, és le kell súlyozni. Az előadáshoz először SzIRÁKI GYÖRGY szólt hozzá, aki szerint a vándorkagyló nem kompetál hazai fajokkal. Előadó kiemelte, hogy ez a faj más kagylók teknőire telepszik, ezzel megakadályozza, hogy beássák magukat az aljzatba - ezáltal valósul meg a kompetíció. SZÖVÉNYI GERGELY arról érdeklődött, hogy találtak-e kvaggakagylót. Szerzők nem akadtak e faj nyomára. SZÖVÉNYI GERGELY: Dunavirágot találtak? A föágban ugyanis honos. GYÖRGY ALEXANDRA: Ezt a fajt sem találták. NAGY PÉTER a hódrágások jelenlétére kérdezett rá. Előadó elmondta, hogy rágást láttak, de élő állatot nem. NAGY PÉTER ezután 
megjegyezte, hogy a diák színösszeállítása nem volt szerencsés. TÖRÖK JÚLIA szerint a diavetítő program különböző verzióinak összeférhetetlensége okozta a szuboptimális látványt. NAGY PÉTER mindazonáltal kiemelte, hogy Előadó a lehetőségekhez képest jól birkózott meg a helyzettel.

3. Jakusovszky Robin, Petrikovszki RenÁta, Kiss Lola VirÁg és NAGy Péter ISTVÁN: Dióavarok ökotoxikológiai vizsgálata talajállatokon.

Bár a dióavar komposztálása aggályokat vet fel, még nem zajlott olyan kutatás, amely a talajfaunára gyakorolt hatását vizsgálta volna. Szerzők négy fonálféreg-, és egy-egy televényféreg-, ill. gilisztafajon vizsgálták a dióavar méreganyagának hatásait. A fonálférgek egy, a televényférgek kettő, míg a giliszták 14 napon át érintkeztek a dióavar hatóanyagaival; a fonálférgek microplate-en, míg a többi féreg talajban. Régebben és frissen lehullott dióleveleket daráltak, és többféle hígítású oldatokat készítettek; ezeket keverték a férgek talajába. Volt olyan féregfaj, amelyre a friss dióavar letálisabb volt, mint a régi avar. Szerzők megfigyelték azt is, hogy a dióavar hatása nem mindegyik fajnál függött a koncentrációjától, és olyan eset is előfordult, amikor a friss avarkivonat koncentrációfüggő mortalitást okozott, míg a régi avar kivonata nem. Két fajnál viszont a töményebb oldatnak erős letális hatása volt. A televényféregnél nem tapasztaltak elhullást a friss avarból készült kivonat esetében. Érdekes eredmény volt, hogy a giliszta testtömege minden koncentrációnál nőtt, míg a kontrollban csökkent. NAGY PÉTER az előadás kiegészítéseként elmondta, hogy az egyik féregfajt valószínüleg nem a megfelelö időben keresték, ezért csak kevés példányt találtak belöle. SZIRÁKI GYÖRGY pontosítani szerette volna, hogy a régi dióavar mennyire volt régi; Előadó válaszából megtudta, hogy egy évnél idősebb. TÖRÖK JÚLIA felvetette, hogy a giliszta talán már alkalmazkodott a dióavar toxinjaihoz, ezért viselhette el. Előadó szerint a szakirodalomban beszámolnak olyan kísérletről, ahol tiszta juglonnak a földigilisztára gyakorolt hatásait vizsgálták, és annak a vizsgálatnak egészen ellentétes lett az eredménye azzal, amit Szerzők tapasztaltak. TÖRÖK JÚLIA: A régi dióavarban módosulhatott a molekula? JAKUSOVSZKY ROBIN: Elképzelhető, de még nem vizsgálták; terveznek kutatást ebben a témában. SZÖVÉNYI GERGELY arról érdeklődött, hogy milyen tanulságot vagy gyakorlati tanácsot lehet adni a gazdáknak a kutatás alapján. Előadó szerint a friss dióavart nem tanácsos felhasználni. SzÖVÉNYI GERGELY: Mit tegyünk az avarral, amíg veszít valamennyit toxikus hatásából? JAKUSOVSZKY ROBIN: Elkülönítve tároljuk. SzÖVÉNYI GERGELY: Milyen élölények bontják le a dióavart? NAGY PÉTER: Bakteriális lebontás történik. BAKONYI GÁBOR megjegyezte, hogy a koncentrációfüggés csak egy küszöbértékig müködik; afölött minden egyedre letális hatással van.

4. Zsemberi Orsolya, Szabó BorbÁla és SÁrospataki Miklós: Bordóilé NEO SC hatásai a földi poszméh (Bombus terrestris) mortalitására és táplálékválasztására.

A háziméheken végzett ilyen témájú kutatások eredményéröl megoszlik a szakirodalom: egyesek taszító, mások mérgező hatásúnak találták a bordóilevet. Ám az eredmények nem ültethetők át teljesen a poszméhekre. Azonban a poszméhek is nagyon fontos beporzó szervezetek, és komoly természetvédelmi jelentőségük is van, ezért Szerzők indokoltnak látták poszméhekkel elvégezni ezt a toxikológiai vizsgálatot. Kutatták a bordóilé akut és orális toxicitását, táplálékválasztási teszttel vizsgálták repellens hatását, és azt is nézték, hogy a talajból fel tudják-e venni a poszméhek toxikus mértékben. Feljegyezték az előforduló rendellenes viselkedéseket is. Ötféle koncentrációjú oldattal találkoztak a poszméh dolgozó egyedek mind a négyféle kísérletben. Az akut orális toxicitás és a táplálékválasztási tesztnél 
a legkisebb koncentráció alig negyede volt az átlagos (előírt) szabadföldi dózisnak, míg a legtöményebb oldat ennek 64-szeresét tartalmazta. A krónikus orális toxicitás vizsgálatához legalább hatszor kisebb volt ehhez képest a koncentráció a hígítási sor minden állomásában, míg a talajtoxicitási teszt esetében négyszer töményebb volt minden adag. Az akut orális toxicitás tesztjénél a szabadföldi kijuttatásnak megfelelő koncentráció 48 óra alatt elpusztította az egyedek felét. A táplálékválasztási tesztből az derült ki, hogy az elöírt kijuttatási dózis még nem volt rájuk riasztó hatással. A krónikus orális toxicitás esetében az derült ki, hogy az átlagos kijuttatási koncentrációnak alig ötöde végez tíz nap alatt az egyedek felével. A talajtoxicitási teszt azt mutatta, hogy a legtöményebb oldat mellett is életben maradt a poszméhek háromnegyede. A mérgezéses tesztekben az életben maradtak között passzivitást, lábgörcsöket és mozgásképtelenséget lehetett megfigyelni. Mindezekből az következik, hogy a bordóilé elfogyasztva toxikus a földi poszméhre: viselkedési zavarokat okoz és letális is lehet, ugyanakkor az elöírt dózisban kijuttatott anyag fogyasztását nem fogják kerülni, mert valószínüleg nem érzékelik. A továbbiakban kifinomultabb talajtoxicitásvizsgálatok kidolgozására lenne szükség, valamint intenzívebben kellene kutatni a növényvédőszerek poszméhekre gyakorolt hatását. Az előadás végén élénk és tartalmas eszmecsere alakult ki. BAKONYI GÁBOR gratulált ehhez az érdekes ökotoxikológiai kutatáshoz. SzIRÁKI GYÖRGY szintén gratulált, jól összeszedettnek tartotta, és afelől érdeklődött, hogy honnan jutottak a poszméhekhez; gyüjtötték-e őket. Előadó elmondta, hogy rendelték a rovarokat. SZÖVÉNYI GERGELY arra kérdezett rá, hogy a talajtoxicitásos vizsgálat során a poszméheket egyesével tartották-e. Előadó igenlő válasza után pedig azt kérdezte meg, hogy vajon nem a magány miatt voltak-e letargikusak a példányok. ZSEMBERI ORSOLYA: Kontroll egyedek is voltak a kísérletben, melyek nem váltak letargikussá, ezek alapján nem a magány váltotta ki ezt a viselkedést. SzÖVÉNYI GERGELY: Mennyire valós a veszély? Hiszen ritkán permeteznek annyira tömény oldattal, mint amilyet a vizsgálatban használtak, ám ha valóban reális a veszély, az súlyos helyzetet vetít előre. ZSEMBERI ORSOLYA: A cukoroldat a nektárforrást modellezte. SZÖVÉNYI GERGELY: Érdekes lenne azt vizsgálni, hogy adott nektárforrásra mennyi permetlé kerül. ZSEMBERI ORSOLYA: Éppen most kezdtek el egy ilyen kísérletet. SzÖVÉNYI GERGELY végül szintén gratulált, és ígéretesnek tartotta az eredményeket. SÁROSPATAKI MIKLÓs közbevetette, hogy a cukoroldatot azért használták a vizsgálatban, mert bordóilével a virágzás alatt is szoktak permetezni. SZIRÁKI GYÖRGY ezután elmondta, hogy a rézvegyületek használata humán toxikológiai vizsgálatok szerint aggályokat vet fel. NAGY PÉTER megkérdezte, hogy a kísérleti berendezések színe befolyásolhatja-e a poszméhek viselkedését. Előadónak nem volt információja a témában. NAGY PÉTER szerint a bordóilé talajba kerülve különböző férgekre és Azotobacter nitrogénkötő baktériumokra is károsan hat. Még egyszer köszöntött minden előadót, és elmondta, hogy az ökotoxikológus MSc képzést kivezetik, ezért ez az előadás „búcsúajándéknak” is tekinthetö. 
1048. előadóülés, 2018. november 7-én

Az ülést ezúttal is NAGY PÉTER elnök úr vezette le.

1. SZABÓ BorbÁla, KoCsis RAMÓNA és MÉZES MiKLÓs: DON és T-2 mikotoxinnal fertözött növényi anyag hatása a Folsomia candida gombafogyasztó ugróvillás (Collembola) fajra.

Előadók vizsgálati alanya egy talajlakó állat, amely tevékenységével szabályozza a talajban élö és a mikorrhiza-kapcsolatokban részt vevő baktériumok egyedszámát. A vizsgált ugróvillás gombafogyasztó volta miatt kézenfekvő volt az ötlet, hogy a mikotoxinok rá gyakorolt hatását kutassák. Ezeket az anyagokat olyan penészgombák termelik (pl. Fusarium fajok), amelyek mindennapi ételeink alapanyagaiban (pl. gabonában) is elöfordulnak. Szerzők nem találtak az irodalomban utalást arra, hogy valaha is vizsgálták volna a mikotoxinok talajfaunára gyakorolt hatását. A kutatásuk egy hónapon át zajlott, az előadás címében említett toxinokat különböző koncentrációkban keverték az ugróvillások táplálékához, és alternatív (nem fertőzött) táplálékot is felkínáltak. A kísérleti állatok túlélését, szaporodását és táplálékfelvételét vizsgálták. Azt találták, hogy a DON toxin már alacsony koncentrációban hatással volt a túlélésre, de a koncentráció növelésével csak kismértékben nőtt a mortalitás. A reprodukció már kismértékü koncentráció-növelés hatására is nagyon visszaesett. A T-2 toxin eleve mérgezőbb, mint a DON, ezért a vizsgálatban alacsonyabb koncentrációkkal dolgoztak. Hatása a DON-éhoz hasonló volt. A táplálékválasztási kísérletben, amikor az ugróvillások egyszerre kaptak fertőzött és toxinmentes táplálékot, először egyáltalán nem észleltek táplálkozást; ezen a ponton arra gondoltak, hogy elrontották a kísérletet. Ám később már fogyasztottak az állatok, és ebből arra lehetett következtetni, hogy a toxin gátolta a táplálkozást. Az irodalom a tyúkoknál hasonló hatást említ, melyet a hormontermelés gátlására vezetnek vissza. Szerzők szerint az ugróvillásoknál inkább a tápcsatorna irritációja lehet a táplálék elutasításának oka. A reprodukció durva visszaesése a táplálkozás és az energia hiányának köszönhető. Ha a DON mellett tiszta táplálékot is adtak, akkor megnőtt a reprodukció gátlásához szükséges koncentráció: a tápcsatorna irritációja később jelentkezett, tovább ettek, így több energiához jutottak. Ha a T-2 mellett volt hozzáférhető alternatív táplálék, akkor viszont megnőtt a mortalitás. Ennek az lehet az oka, hogy a T-2 olyan kis koncentrációban van jelen, hogy a jelenlétét még nem érzik, de letális hatását már kifejti. Az eredményekből Szerzők azt a konklúziót vonták le, hogy a mikotoxinokat tartalmazó növényi anyagokat nem szabad beszántani a talajba, mert a toxinok kis koncentrációban is mérgezik a talajt. Az előadás végén NAGY PÉTER arról érdeklődött, hogy léteznek-e olyan kísérletek, amelyek a talajba forgatott növényi anyagokhoz adott inhibitorok hatásait vizsgálják. Előadó szerint nincsenek ilyenek, mivel övék az első kutatás ebben a témakörben. Gyakorlati javaslata az, hogy a beforgatandó növényi részeket előbb komposztálják, mert ekkor a mikotoxinok bakteriális lebontást szenvednek. JÁNOSSY LÁSZLÓ kérdése az volt, hogy a gazda honnan tudhatja, hogy toxinmentes növényi anyagot szánt-e be. Előadó szerint a gazdáknak kötelességük tudni ezt. NAGY PÉTER: Valóban tudják is? SZABÓ BORBÁLA: Előírás van erre, ellenőrizni kell a takarmányt. NAGY PÉTER végül felvetette, hogy egyes vélemények szerint a mikotoxinok újabb fegyvert jelentenek a felvásárlók kezében, ám szerencsére ennél azért árnyaltabb a helyzet. 
2. Zsinka BernadetT, KÖVÉR SZILVIA, PÁSZTORY-KovÁCs SZILVIA, VILI NóRA, SZABÓ KRISZTIÁN, FATÉr IMRE és HoRvÁTH MÁRTON: A Magyarországon költö parlagi sasok túlélésének becslése vedlett és fiókákból tépett tollakból meghatározott genotípusok alapján.

A parlagi sas eurázsiai elterjedésű faj, ám európai állományának nagy része Magyarországon honos. A nőstény madarak nagyobb termetüek, mint a hím egyedek. Az 1970-es és 1980-as évek folyamán a hazai állomány jelentősen lecsökkent és főleg az Északiközéphegységbe szorult vissza a faj, ám azóta örvendetesen nő az egyedszám, és az Alföldön is fészkel. A példányok elhullásának vezető oka a mérgezés (akár szándékosan, akár akaratlanul; pl. rágcsálók ellen), második helyen áll az áramütés, és a gázolás a harmadik a sorban. Az elmúlt években a saspopuláció megerősítését szolgáló LIFE-projekt zajlott. A túlélés becsléséhez általában a jelölés-visszafogás módszerét használják, de ez sasoknál nem kivitelezhetö. Alternatív módszerként tollakat gyüjtöttek be a fészkek környékén, valamint fiókákból téptek tollakat, és az ezekben maradt vérből kivont DNS-t használták kormeghatározásra és az egyedek azonosítására. A mintavétel a LIFE-program teljes ideje alatt zajlott. Bár nem sikerült minden évben minden szülötől mintát venni, a rokonok genotípusából mégis sikerült következtetni jelenlétére (indirekt jelenlét). A legtöbb mintázott egyed nőstény volt. A látszólagos túlélést a valódi túléléssel egyenlőnek tekintették (pl. az elvándorlás okozhat különbségeket). Az adataikat különféle modellekbe táplálták, és a következő eredményeket kapták: (1) a hímek túlélési esélyei alacsonyabbak, mint a nőstényeké - valószínüleg azért, mert többet vadásznak, így több veszély érheti öket, (2) az évek múlásával csökkent a mérgezés elszenvedésének esélye, és a túlélés kicsit nőtt. A LIFEprojektben folyamatosan zajlott a sasok monitoringja, tetemkereső és mérgezett csalikat kereső kutyák kiképzésére került sor, mérgezéseket kezelő állomásokat alakítottak ki, őrizték a fészkeket, és együttmüködést alakítottak ki a rendőrséggel, aminek köszönhetően sikerült néhány esetben felelősségre vonni a mérget kihelyező tetteseket. Szerzők további terve, hogy modelljeikbe beépítik az életkort, mert szeretnének magyarázatot találni arra a jelenségre, hogy az újonnan felbukkant egyedeket később kevesebbszer észlelték, mint a régebb óta ott élő példányokat.

Az előadás után tartalmas eszmecsere bontakozott ki. A kérdések sorát JÁNOSSY LÁsZLÓ nyitotta, aki afelől érdeklődött, hogy a túlélés mindig a következő évre vonatkozott-e; Előadótól igenlő választ kapott. JÁNOSSY LÁsZLÓ: Lehetett-e gyürüzési adatok alapján pontosan megállapítani az egyedek korát? ZSINKA BERNADETT: Inkább a természetvédelmi őrök ismereteire és a DNS-vizsgálat eredményeire támaszkodtak a kor meghatározásánál. JÁNOSSY LÁsZLÓ: Néhány évtizede találtak egy nagyon idős sast, annak életkorát a gyürüjéből tudták meg. ZSINKA BERNADETT: a vizsgálatukban részt vevő egyedek közül 22 éves volt a legidősebb. SZÖVÉNYI GERGELY a kutyás keresések menetét szerette volna megtudni. Előadó azt közölte, hogy ha valaki tetemet talál, akkor a kutyával kimennek hozzá, és a környéken nagy területet átfésülnek, mert gyakran előfordulnak további mérgezett példányok is. NAGY PÉTER azt kérdezte meg, hogy az egyes ivaroknál történt-e korcsoportvizsgálat. Előadó elmondta, hogy nem volt ilyen. NAGY PÉTER: Vizsgálták-e a hütlenséget? ZSINKA BERNADETT: A sasokra nem jellemző ez a viselkedésforma. SZÖVÉNYI GERGELY: A hullott tollakban mennyi időn át marad meg a DNS olyan állapotban, hogy értékelhető hosszúságú szekvenciákat lehessen izolálni belőle? ZsINKA BERNADETT: A napfény és a nedvesség erősen degradáló hatású; nyáron néha pár hónapig megmarad a lehetőség, de a 
telet nem vészeli át a DNS épségben. A begyüjtött tollakat szobahőmérsékleten és sötétben tartják, így több hónapon át mintavételre alkalmasak maradnak. NAGY PÉTER végül felvetette, hogy érdemes lenne vizsgálni a mikotoxinoknak a táplálékláncban mutatkozó hatását.

3. KACZ PÉTER, HorvÁTH MÁRTON, FATÉr IMRE, JUHÁSZ TIBOR és PÁSZTORY-KovÁCS SzILVIA: Magyarországi parlagi sas fiókák morfológiai ivarmeghatározása.

A parlagi sas egyedek ivarát a tollazat jellemzői alapján nem lehet megállapítani, de a méret, a viselkedés és a túlélés egyaránt ivari dimorfizmust mutat. A fiatalok ivararánya nem azonos a felnőttekével, de ennek vizsgálatához DNS-mintavétel szükséges, amely még mindig elég drága, ráadásul invaziv. Olyan módszerre lenne szükség, amelynek nincsenek meg az előbb említett hátrányai. Szerzők kutatásának célja olyan morfológiai változók felfedezése volt, melyek eltérnek a két ivarnál. 4-9 hetes fiókákon végezték méréseiket, meggyürüzték őket, és hónaljtollukból DNS-mintát is vettek referencia gyanánt. Egyes testtájak tollazata alapján korbecslést végeztek, fényképeken dokumentálták az egyedeket. Mérték a tarsus, a hátulsó karom és a farktollak hosszát, valamint az állatok tömegét. A DNS-alapú ivarmeghatározást gélelektroforézis segítségével végezték, ahol szétváltak az ivari kromoszómák. Korrelációt számoltak a becsült életkor és a morfológiai változók között, az adatokat háromféle módszerrel (döntési fa, véletlen erdők és lineáris diszkriminancia-analízis) elemezték. Kiderült, hogy a hátulsó karom hossza már igen fiatalon eltér a két ivar között, míg a testtömeg eltérése csak idősebb korban jelentkezik. A tarsus hosszában is csak idősebb korban tér el a két ivar. A farktollak hossza ivari dimorfizmust egyáltalán nem mutat, de korbecslésre használható. A döntési fa alapján legfontosabb a karomhossz volt; a nőstényeké nagyobb volt, mint a hímeké. A véletlen erdők módszerével ugyanezt találták, a második legfontosabb a tarsus átmérője, végül a testtömeg volt. A karomhossz különleges fontosságát a diszkriminancia-analízis szintén alátámasztotta. Összegzésképpen elmondható, hogy a hátulsó karom hosszának mérése a legfontosabb az ivar meghatározásához, a testtömegböl az életkorra lehet következtetni, míg a tarsus hossza egyik szempontból sem hordoz információt, ennek mérésétől el lehet tekinteni, így a gyürüzés folyamata gyorsabbá válik. Eredményeiknek gyakorlati haszna is lett, ugyanis lehetségessé vált egy terepi ivarhatározó összeállítása. NAGY PÉTER tette fel azt a kérdést, hogy vizsgáltak-e egyéb jellemzőket. Előadó elmondta, hogy feljegyezték az esetleges elváltozásokat. NAGY PÉTER: A kloáka ivarok közti eltéréseit is vizsgálták? KACZ PÉTER: Ezt nem nézték. NAGY PÉTER: Naposcsibéket szexáltak a kloáka jellemzői alapján. KACZ PÉTER: Erről nem volt tudomásuk; a szárnyhosszt jegyezték még fel. NAGY PÉTER: Azért is fontos lenne tudnunk az egészséges populációk ivararányát, mert léteznek hormonhatású szennyezőanyagok, amelyek eltolhatják a nemek arányát. JÁNOSSY LÁSZLÓ közölte, hogy ő is hallott a kloáka alapján történő szexálásról naposcsibéknél, és javasolta Előadónak, hogy járjanak utána az irodalomban, és vizsgálják jövőben a sasoknál is ezt a jellemzőt. NAGY PÉTER végül sok sikert kívánt a további kutatásokhoz, és felhívta a figyelmet arra, hogy mindkét sasokkal foglalkozó előadást olyan személyek mutatták be, akik először szerepeltek a Szakosztály ülésein.

4. SARLÓS DÁVID: Egy kanadai nemzetközi konferencia (27th International Ornithological Congress) tapasztalatai - élménybeszámoló.

Szerző a Szent István Egyetem Állattani Tanszékén a szalakóták életmenetének kutatásával foglalkozik doktoranduszként. Campus Mundi ösztöndíjat nyert, ebből jutott el a világ egyik legnagyobb madarász konferenciájára. Összesen 2000 résztvevője volt az eseménynek, akik több mint száz országból érkeztek igen sokféle témájú előadással vagy 
poszterrel. Ezt a konferenciát négyévente rendezik, és hét napon át szokott tartani. Előadó néhány nappal a konferencia előtt érkezett Kanadába, és néhány nappal a vége után jött haza. Meglátogatta a Queen Elizabeth Parkot, ahol sikerült kolibriket fényképeznie. A parkon belül található az üvegházra emlékeztető Bloedel Conservatory, amelyben sok papagájt tartanak, és ahol Előadó sokkal több látogatóval találkozott, mint a park többi részén. A Van Dusen Botanikus Kertben szelíd kanadai ludakat figyelt meg, és kipróbálhatta tájékozódási képességét egy élősövényböl létrehozott terjedelmes labirintusban. A konferencia helyszínén a bőség zavarával küszködött, ugyanis 150 elöadóterem, 50-60 párhuzamosan futó előadás és mintegy 300 , kétnaponta cserélt poszter várta. Érdekesség gyanánt megmutatott egy különálló lapokból összetüzdelt, jegyzetszerü poszterröl készített fényképet, melynek tulajdonosával szeretett volna találkozni, ám egyszer sem találta. Bár zömmel helyiek vettek részt a konferencián, már a megnyitóünnepségen találkozott magyarokkal. A konferenciával párhuzamosan madárfesztivál zajlott, ahol mindenféle, madarakhoz és azok megfigyeléséhez kapcsolódó kiállitást is meg lehetett tekinteni. A szakmai programot vezetett túrák színesítették, amelyek úticéljai a város környéki hegyektől egészen a Galápagos-szigetekig terjedtek. Szerző egy környékbeli túrán vett részt, ahol egy tanösvény, gyönyörü panoráma és cirkuszszerủ állatbemutató fogadták. A konferencia utáni napokban meglátogatta a helyi egyetem természettudományi múzeumát, itt olyan nyalókákat lehetett kipróbálni, melybe ízeltlábúak voltak ágyazva. Bálnanéző túrán is részt vett, eleinte „csak” fókákat láttak, később messziről figyelhettek egy kardszárnyú delfint, ám végül a közelükben is elhaladt egy példány. A Reifel vonulómadár-élöhelyen is járt, a tavak közt vezető tanösvényen kevés madárfaj sok egyedét figyelhette meg. Hazafelé Torontóban szállt át, és a hosszú átszállási időnek köszönhetően megtekinthette a Niagara-vízesést hajóból és a partról is. Összességében rengeteg pozitív élményben volt része, melyek közül az emberek segítőkészségét, a szép környezetet és a konferencia profi megszervezését emelte ki. Ugyanakkor nehézséget okozott Előadónak a hosszú repülőút és a nagy időeltolódás. Az előadást Szerző saját készítésü képeivel gazdagon illusztrálta. NAGY PÉTER kérdezte meg, hogy több magyar is részt vett-e a konferencián. Előadónak a megnyitón megismert emberek mondták, rajtuk kívül 5-6 magyarról tudnak, köztük Bozó LÁsZLÓról. NAGY PÉTER végül megköszönte az elöadóknak és a hallgatóságnak a részvételt. 